\title{
The value of human epididymis protein 4 (HE4) as a serum tumor marker for accurate bone metastases finding by whole-body bone scintigraphy in lung cancer patients
}

\author{
J. WEISSENSTEINER ${ }^{1}$, E. BABUSIKOVA ${ }^{2, *}$ \\ ${ }^{1}$ Department of Nuclear Medicine, Hospital Poprad, Poprad, Slovak Republic; ${ }^{2}$ Comenius University in Bratislava, Jessenius Faculty of Medicine \\ in Martin, Department of Medical Biochemistry, Martin, Slovak Republic \\ *Correspondence: babusikova@jfmed.uniba.sk
}

Received December 12, 2018 / Accepted May 29, 2019

\begin{abstract}
The aim of our study was to correlate the serum concentration of human epididymis protein 4 (HE4) in lung cancer patients with the bone metastases detected by whole-body bone scintigraphy. The serum concentrations of HE4 were determined by electrochemiluminescence immunoassay (ELISA) method in 60 patients with lung cancer and in 10 persons without malignant disease (control group). All participants were examined by whole-body bone scintigraphy with hybrid gamma camera of type BrightView XCT. We found bone metastases in $25.0 \%$ of patients by whole-body bone scintigraphy and probable bone metastases in $18.3 \%$ of patients. We did not observe bone metastases in $56.7 \%$ of patients and in nobody from control group. We observed that $73.33 \%$ patients with bone metastases had more than 3 bone metastasis deposits. Patients had significantly increased concentration of HE4 ( $\mathrm{p}<0.0001)$. All three subgroups of patients (bone metastases, probable bone metastases, no evidence of bone metastases) had significantly increased concentration of HE4 compared to controls. The highest concentration of HE4 had 9 patients with small-cell lung cancer of whose 4 patients had bone metastases, 4 patients had probable bone metastases and one patient was with no evidence of bone metastases. We found that HE4 has a discriminatory ability to differentiate groups of patients and healthy controls, as well as within scaffold scintigraphy in patients with lung cancer $(\mathrm{p}=0.0002)$. The serum concentration of human epididymis protein 4 was significantly increased in patients with lung cancer in comparison with persons of control group. A quarter of lung cancer patients had identified bone metastases by whole-body bone scintigraphy and approximately $20 \%$ of patients had probable bone metastases. The increasing serum concentrations of human epididymis protein 4 can have importance in the diagnosis of bone metastases in patients with lung cancer, in particular in small-cell lung cancer.
\end{abstract}

Key words: lung cancer, bone metastasis, human epididymis protein 4, bone scintigraphy

Lung cancer (LC) is the second most commonly diagnosed oncological disease and remains the major cause of human mortality among all the malignancies in the world, with 1.3 million of malignancy-related deaths per year [1-5]. The prognosis of lung cancer is still poor. There are some potential biochemical markers to diagnose of LC (serum carcinoembryonic antigen, neuron specific enolase, cytokeratin fragment, tissue polypeptide specific antigen and progastrinrelapsing peptide) but the clinical values of them are limited. Incidence rates of LC are between 2/100000 - 80/100000 for men and 1/100000 - 39/100000 for women. Non-small-cell lung cancer (NSCLC) consists $80-85 \%$ from all cases of LC [6]. The main risk factor of LC is smoking, which contribute to $80 \%$ of cases. Other risk factors are genetic predisposition, environmental exposures to asbestos, arsenic, radon, polycyclic aromatic hydrocarbons, other cancer-causing agents in the workplace and air pollution $[7,8]$.

Diagnosis of bone metastases has been performed by whole-body bone scintigraphy with ${ }^{99 \mathrm{~m}} \mathrm{Tc}$-labelled radiopharmaceuticals, such as Technetium-99m - methylene diphosphonate ( ${ }^{99 \mathrm{~m} T c-M D P}$ ) for many years. Whole-body bone scintigraphy is an available, non-invasive and sensitive nuclear medicine imaging. This method is able to find bone metastases several months before they are visible in conventional radiographs. Single photon emission computed tomography/computed tomography (SPECT/CT) as a hybrid imaging after whole-body bone scintigraphy can provide more accurate localization of the pathological lesion to the 
anatomical structures and better diagnosis of bone metastases $[9,10]$.

In clinical practice, human epididymis protein 4 (HE4) is used as a tumor marker. Human epididymis protein 4 is $20-25 \mathrm{kDa}$ secretory glycoprotein with similar structure to protease inhibitors. This glycoprotein is encoded by gene whey acidic protein (WAP) 4-disulphide core domain 2 (WFDC2) located on chromosome 20q12-q13.1 [11]. Gene is a member of the whey acidic protein domain family, and this domain shows fifty well-conserved amino acid motifs. The function of HE4 is not very well-known. Kirchhoff et al. identified and described HE4 for the first time as a product of epididymis tissue $[12,13]$. It is supposed that this protein is inhibitor of trypsin and can participate on sperm maturation [14]. Increased expression of HE4 gene was found in epithelium of respiratory and reproductive tract [15]. Nowadays HE4 is used as a useful clinical marker in patients with ovarian cancer for diagnosis, prognosis and early recurrence monitoring after surgery $[16,17]$. Increased HE4 concentrations were observed in several oncological diseases. Human epididymis protein 4 can be a potential marker in endometrial carcinoma, mammary adenocarcinoma, lung carcinoma, mesothelioma, pancreatic metaplasia and intestinal metaplasia of the stomach [18-24]. However, the function of HE4 in lung carcinoma is unclear.

\section{Patients and methods}

Patients. Our study population consisted of 60 patients (46 men and 14 women, mean age 66.65 years, range $50-84$ years) with diagnosis of lung cancer. In 50 patients were presented non-small-cell lung cancer (NSCLC), in 9 patients small-cell lung cancer (SCLC) and one patient had atypical lung carcinoid tumor. The group of NSCLC presented 21 patients with squamous cell carcinoma, 20 patients with adenocarcinoma, 3 with large cell carcinoma, 3 non-small-cell lung cancers with neuroendocrine component and 3 non-small-cell lung cancers not otherwise specified (NSCLC-NOS) (summarized in Table 1). The diagnosis of lung cancer was based on the combination of clinical findings, results of imaging methods, including X-ray, computed tomography (CT) of thorax and histological demonstration.

Healthy controls. Control group represented 10 persons without oncological diagnosis ( 2 men, 8 women, mean age 52.3 , and range $34-67$ years). These persons had unclear pain in backbone or joints. All procedures performed in our study involving human participants were in concordance with the ethical standards and with the 1964 Helsinki declaration. Informed consent was obtained from all individual participants included in the study.

Bone scintigraphy. Whole-body bone scintigraphy examinations were obtained using a double-head gammacamera, a hybrid SPECT/CT scanner type BrightView XCT, Philips Healthcare with a built-in flat-panel CT detector. The whole-body scanning of skeleton was acquired 2 to 4 hours after intravenous application of 600-700 megabecquerels (MBq) or 16-19 millicuries ( $\mathrm{mCi}$ ) of radioactive tracer Technetium-99m - Methylene diphosphonate ( ${ }^{99 m}$ Tc-MDP) with movement of bed examination with patient between two stationary detectors located above and under patient by using a low-energy general-purpose (LEGP) parallelhole collimator. The scanning speed was $10-12$ centimeters/ minute between two detectors. Additional static images (500 kcounts) of the skull (lateral views) with matrix $128 \times 128$ and $256 \times 256$ were performed in all participants. For precise location of lesion in the skeleton, the hybrid imaging SPECT/ CT has been added with two detectors of SPECT, which rotated $180^{\circ}$ counter-clockwise and circular around interest part of patient's body in 64 steps for 20-30 seconds for one step with matrix size $128 \times 128$. In next step location CT with X-ray parameters: current 20-80 milliamperes-seconds, voltage 120 kilovolts, slice thickness: 1 millimeter and matrix size: $512 \times 512$ with one (14.4 centimeters) or three (43.2 centimeters) of segments of CT. SPECT and CT images were fused by software (Extended Brilliance Workspace, Philips Healthcare).

Image of whole-body bone scintigraphy analysis and interpretation. Bone scintigraphy were interpreted by one or two nuclear medicine physicians by visual analysis, after taking into consideration the location, multiplicity, distribution, uptake pattern and trauma history. Each image interpretation was performed using a 3-point scale (definite bone metastases, probable bone metastases, no evidence of bone metastases).

Sample collection and laboratory examinations of HE4 levels in the serum. Five - six $\mathrm{ml}$ of peripheral venous blood were obtained from lung cancer patients and controls

Table 1. Characteristics of lung cancer patients.

\begin{tabular}{lc}
\hline Characteristic & Patients (n, \%) \\
\hline Diagnosed lung cancer & 60 \\
Age (years), mean & 66.65 \\
Range (years) & $50-84$ \\
Gender & \\
Male & $46(76.67 \%)$ \\
Female & $14(23.33 \%)$ \\
Cell type of lung cancer & \\
SCLC & $9(15 \%)$ \\
Typical lung carcinoid tumor & $1(1.67 \%)$ \\
NSCLC & $50(83.33 \%)$ \\
Subtypes of NSCLC & \\
Squamous cell carcinoma & $21(35 \%)$ \\
Adenocarcinoma & $20(33.33 \%)$ \\
Large cell carcinoma & $3(5 \%)$ \\
NSCLC, with neuroendocrine component & $3(5 \%)$ \\
NSCLC-NOS & $3(5 \%)$ \\
\hline
\end{tabular}

$\mathrm{n}$ - number of patients, SCLC - small-cell lung cancer, NSCLC - nonsmall-cell lung cancer, NSCLC-NOS - non-small-cell lung cancer not otherwise specified 


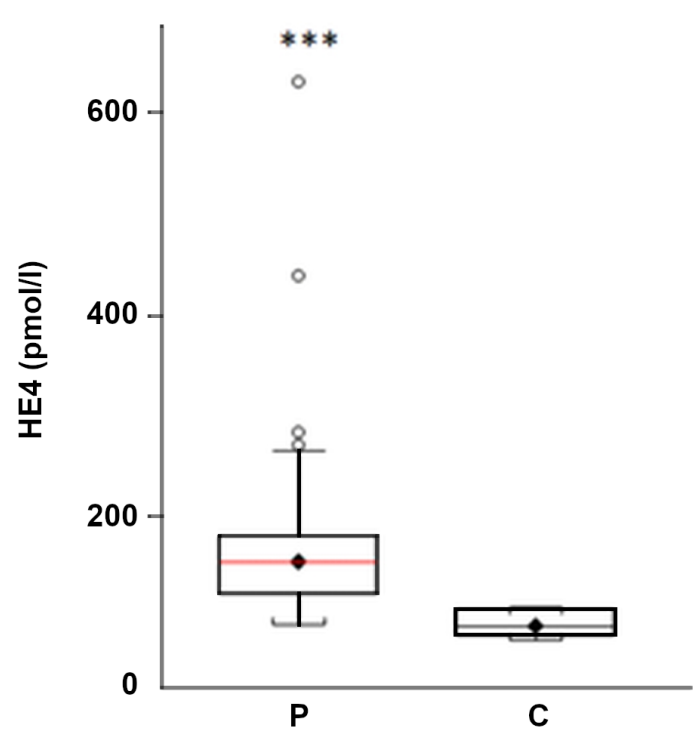

Figure 1. Serum concentration of HE4. P - patients with lung cancer, $\mathrm{C}$ - control group; ${ }^{* * *} \mathrm{p}<\mathbf{0 . 0 0 0 1}$ significant difference between medians of HE4 in patients with lung cancer and control group.

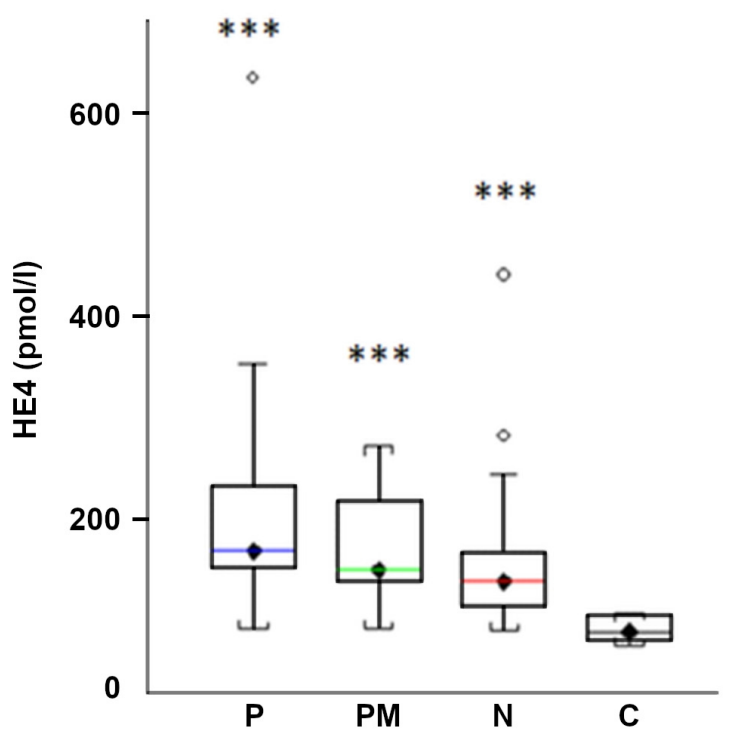

Figure 2. Serum concentration of HE4 on basis of 3-point scale whole body bone analysis. $\mathrm{P}$ - definite bone metastases, $\mathrm{PM}$ - probable bone metastases, $\mathbf{N}$ - no evidence of bone metastases, $\mathrm{C}$ - control group; ${ }^{* * *} \mathrm{p}<0.0001$ significant difference between medians of $\mathrm{HE} 4$ in patients with lung cancer and control group.

Table 2. Bone metastases in lung cancer patients.

\begin{tabular}{lc}
\hline Bone metastases & Patients (n, \%) \\
\hline Definite bone metastases & $15(25 \%)$ \\
Probable bone metastases & $11(18.3 \%)$ \\
No evidence of bone metastases & $34(56.7 \%)$ \\
3 and less than 3 bone metastases & $4(26.67 \%)$ \\
More than 3 bone metastases & $11(73.33 \%)$ \\
\hline
\end{tabular}

$\mathrm{n}$ - number of patients samples before intravenous injection the whole-body bone scintigraphy radioactive agent ${ }^{99 \mathrm{~m} T \mathrm{Tc}-\mathrm{MDP} \text {. Blood samples }}$ were kept in room temperature for 1-2 hours and then centrifuged at 4000 revolutions per minute for 5 minutes. The obtained serum was stored in aliquots at $-50^{\circ} \mathrm{C}$ until assayed. Serum concentrations of HE4 were measured with automated electrochemiluminescence immunoassay equipment (Elecsys, Roche Diagnostics) at the Department of Clinical Biochemistry (University Hospital Martin, Comenius University in Bratislava, Slovak Republic) by using immunoassay analyzer of type Cobas e 411 (Roche). In this study we used reference values: HE $4 \leq 140 \mathrm{pmol} / \mathrm{l}$.

Statistical analyses. Data were analyzed by software Statsdirect version 2.8.0. Statsdirect Ltd. (Statsdirect statistical software http://statsdirect.come). Unpaired t test and Mann-Whitney $\mathrm{U}$ test were used for simple analysis between patients and control subjects. We used descriptive statistics, Kruskal-Wallis test, all pairwise comparisons (ConoverInman), Squared ranks approximate equality of variance test for analysis between subgroups of patients and control subjects. P-values $<0.05$ were considered to be significant.

\section{Results}

In our study, whole-body bone scintigraphy was performed in lung cancer patients and in healthy control subjects. Using a 3-point scale (definite bone metastases - $\mathrm{P}$, probable bone metastases - PM, no evidence of bone metastases - N) we found that $25 \%$ of patients had bone metastases, $18.3 \%$ of patients had probable bone metastases and $56.7 \%$ patients were without bone metastases (Table 2). Bone metastases were localized mostly in vertebra (80\%), rib (73.33\%) and pelvis (66.67\%). Majority of patients with bone metastases (73.33\%) had more than 3 deposits of bone metastases. We did not find bone metastases by whole-body bone scintigraphy in healthy control subjects. We did not observe any significant changes by comparison of patients with definite bone metastases with localization of bone metastases, age and gender.

We observed significant difference in HE4 serum concentration between group of lung cancer patients and control group $(\mathrm{p}<0.0001)$ (Figure 1). Patients with bone metastases had significantly increased $(\mathrm{p}<0.0001)$ concentration of HE4 compared to controls (Figure 2). Similarly, patients with probable bone metastases or without bone metastases had significantly increased concentration compared to controls (Figure 2). We did not observe a statistically significant difference between patients with definite bone metastases, probable bone metastases and no bone metastases. We found out variances difference between patients with definite metastases and patients with no evidence of bone metastases but because of small number of patients it was not statistically significant. Complex statistical analysis showed that concentration of HE4 has a discriminatory ability to differentiate groups of patients and control group, as well as within scaffold scintigraphy in patients with lung cancer $(\mathrm{p}=0.0002)$. 
We analyzed HE4 concentration on the basis of different histological type of lung cancer. We observed statistically significant increased concentration of HE4 in patients compared to control group (Figure 1). Patients with diagnosed small-cell lung cancer had significantly increased $(\mathrm{p}=0.006) \mathrm{HE} 4$ concentration also compared to patients with non-small-cell lung cancer (Figure 3). Sixty percent of SCLC patients had HE4 concentration above physiological range (Table 3). All these patients had or probably had bone metastases. Patient with atypical lung carcinoid tumor had definite bone metastases and increased HE4 concentration above physiological range. All subjects in control group had HE4 concentrations within physiological range.

We did not observe any significant changes in HE4 concentrations by comparison patients with cancer treatment (surgery of primary malignant tumor, chemotherapy or radiotherapy) and patients without treatment. However, patients without any cancer treatment had higher concentrations of HE4.

\section{Discussion}

Normal bone metabolism is changed in patients with bone metastases. Usually higher osteoclastic activity is observed during development of bone metastases. Bone metastases contribute to origin or development of several complications, such as pains, pathological fractures and hypercalcemia. Destruction of spine by bone metastases can cause the compression of vertebras and spinal cord that results in decreased quality of patient's life $[25,26]$.

In our study, we probed bone metastases in patients with lung cancer and we analyzed possible using of serum HE4 as a diagnostic and/or prognostic marker of lung cancer with developed bone metastases. We found definite bone metastases in $25 \%$ of patients and probable bone metastases in $18.3 \%$ of lung cancer patients. Furthermore $73.33 \%$ of patients had more than 3 bone metastases. We observed significantly increased concentration of HE4 in lung cancer patients compared to healthy controls. Kruskal-Wallis test revealed that serum HE4 concentration had a discriminatory ability to distinguish patients with lung cancer from healthy controls as well as within scaffold scintigraphy in patients with lung cancer ( $\mathrm{p}=0.0002)$. The serum HE4 concentrations were in all cases of lung cancer patients with bone metastases higher than in healthy controls. Using hybrid scanning by single photon emission computed tomography/computed tomography (SPECT/CT) of selected part of body or whole-body helps to better diagnose the presence of bone metastases and to assess the type of lesion (osteoblastic, osteolytic or mixed-lesion). On the other side, because of long time of scanning of wholebody and higher dose of radiation to tissues, it is not used in clinical practice routinely. Evaluation of HE4 concentration by available ELISA kits may be potentially used as a diagnosis/ prognostic marker of the bone metastases in patients with lung cancer especially with small-cell lung cancer.
Human epididymis protein 4 (HE4, WFDC2) is one of 14 homologous genes, which encode family of proteins with a whey acidic protein and 4-disulphide core domain 2 [11]. It has been suggested that HE4 participates in physiological processes: natural immunity, antimicrobial activity, protease inhibitors, regulation of extracellular matrix, cell migration and cell invasion. However, HE4 can also participate in pathological processes. Nowadays HE4 is one of the most intensively studied biomarker. HE4 is used as a biomarker for diagnosis, monitoring and prognosis in ovarian adenocarcinoma and endometrial cancer [27-31]. Concentrations of HE4 are different in premenopausal or postmenopausal woman and can be influenced by age, smoking and

Table 3. HE4 concentration above physiological value.

\begin{tabular}{lccc}
\hline Categories & $\begin{array}{c}\text { Definite bone } \\
\text { metastases } \\
(\mathbf{n}, \mathbf{\%})\end{array}$ & $\begin{array}{c}\text { Probable bone } \\
\text { metastases } \\
(\mathbf{n}, \mathbf{\%})\end{array}$ & $\begin{array}{c}\text { No evidence of } \\
\text { bone metastases } \\
(\mathbf{n}, \mathbf{\%})\end{array}$ \\
\hline AC & $1(100 \%)$ & - & - \\
SCLC & $4(100 \%)$ & $2(50 \%)$ & - \\
NSCLC & $2(20 \%)$ & $1(14.29 \%)$ & $8(24.24 \%)$ \\
Gender & & & $6(25 \%)$ \\
\multicolumn{1}{c}{ Male } & $5(41.67 \%)$ & $3(30 \%)$ & $2(20 \%)$ \\
Female & $2(66.67 \%)$ & - & $8(23.53 \%)$ \\
Total & $7(46.67 \%)$ & $3(27.27 \%)$ & \\
\hline
\end{tabular}

$\mathrm{n}$ - number of patients, AC - atypical lung carcinoid tumor, SCLC - smallcell lung cancer, NSCLC - non-small-cell lung cancer

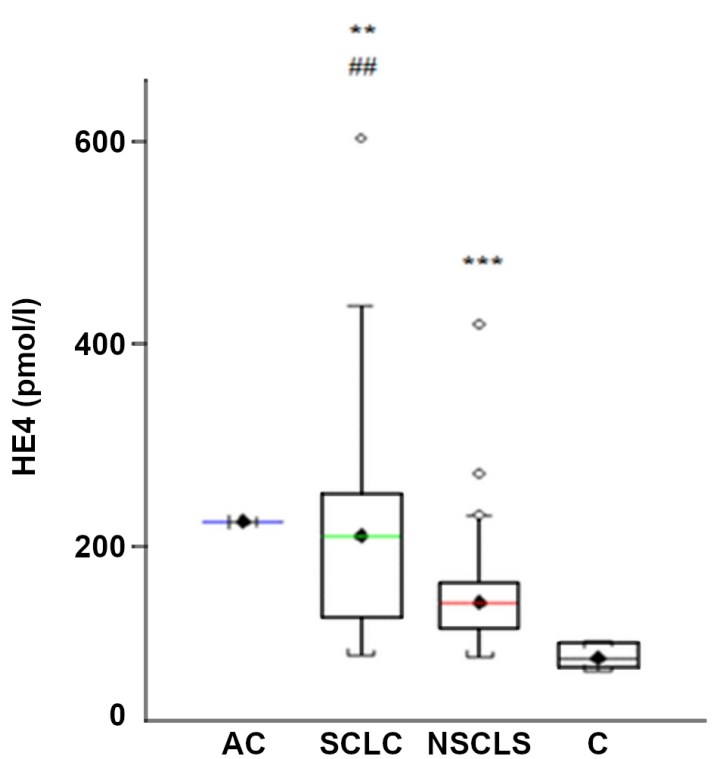

Figure 3. Serum concentration of HE4 in patients with different histological types of lung cancer. AC - atypical lung carcinoid tumor, SCLC - small-cell lung cancer, NSCLC - non-small-cell lung cancer, C - control group. ${ }^{\star *} \mathbf{p}<\mathbf{0 . 0 1}$ significantly different as compared to control group; ${ }_{* * *} \mathbf{p}<\mathbf{0 . 0 0 1}$ significantly different as compared to control group; \#\# $\mathrm{p}<0.01$ significantly different as compared to patients with non-smallcell lung cancer. 
function of kidneys. Therefore, all these factors need to be taken into consideration in proper clinical interpretation of results. Increased expression of WFDC2 was found in different malignant tumors and also in some type of lung cancer especially in small-cell lung cancer, squamous cell carcinoma, adenocarcinoma, large cell carcinoma of lung [32-36]. Drapkin et al. suggested that HE4 is a secreted glycoprotein presented in the circulation and plays a role in the cancer biology [37]. In our previous study, we observed the moderate increase of the HE4 concentration in the serum during the entry examination and the check-up of the whole-body bone scintigraphy with equivocal finding of bone metastases in 64 years old female with malignant melanoma [38].

We showed that HE4 concentration was the highest in patients with bone metastases and in patients with smallcell lung cancer. Our results are in compliance with similar studies, however studies with Caucasian population are very rare in the literature. The alternative expression of WFDC2 may be associated with lung carcinogenesis and tumor progression what is in an agreement with Yamashita et al. hypothesis [19]. Zeng et al. suggested that HE4 is a better biomarker than others in diagnosing of early stage of lung cancer [39]. Diagnosis of early stages of lung cancer is crucial for patient survival and is still poor. Patients with HE4 positive adenocarcinoma had a worse prognosis than patients with HE4 negative adenocarcinoma [19, 40]. HE4 concentrations may be used as potential biomarkers to differentiate pulmonary tuberculosis from lung cancer [42]. Increased levels of HE4 in serum and tumor tissues were found in SCLC patients [20, 41, 42]. However, the difference in HE4 serum concentrations between SLLC and NSCLC was not significant [20, 41]. Tang et al. observed significantly higher serum concentrations of carcinoma embryonic antigen, cytokeratin fragment 21 , neuro specific enolase and HE4 in pulmonary carcinoma patients than in controls [36]. We observed significantly increased concentration of HE4 in SCLC compared to controls and also to NSCLC. Our observation may be explained that all SCLC patients had bone metastases. Previous studies showed that HE4 is a potential marker for the diagnosis and follow up of NSCLC patients and could be helpful in evaluation of SCLC patient's prognosis $[43,44]$. Celik and Bulut observed that HE4 is expressed in adenocarcinoma tissues but it is not frequent in SCLC [45]. It was suggested that serum HE4 concentration can discriminate those with response to chemotherapy/chemoradiotherapy from those who are resistant to chemotherapy [20,46] and expression of HE4 is associated with a worse prognosis in patients with lung cancer [47]. In our study, we compared serum HE4 concentrations in patients who underwent treatment (surgery of primary malignant tumor of lung, chemotherapy, radiotherapy) with patients without treatment. We found that patients without surgery of primary malignant lung tumor had higher HE4 concentration. Increased levels of HE4 in patients with different oncological diseases may be important for tumor growth and survival signaling. HE4 induces chemoresistance to anti-cancer drugs and activates the AKT and Erk pathways to enhance tumor survival [48]. Jiang et al. found higher HE4 expression in patients with NSCLC in correlation with stage of disease $(p=0.003)$, lymph node metastases $(\mathrm{p}=0.007)$ and distant metastases $(\mathrm{p}<0.001)$ [49]. Lamy et al. observed significantly higher concentrations of $\mathrm{HE} 4$ in patients with worse performance status, advanced stage of disease and positive nodal status [50]. We did not find significantly correlation between $\mathrm{HE} 4$ concentrations in the serum and metastases findings in different organs of lung cancer patients. All patients with SCLC had bone metastases and their serum HE4 concentration was the highest and probable increased production of HE4 is a feature of tumor progression.

In conclusion, the serum concentrations of HE4 were significantly elevated in lung cancer patients in comparison to healthy controls. The increasing trend of serum HE4 is present in all patients with lung cancer in our study group. Evaluation of HE4 concentration by available ELISA kits may be potentially used as a diagnosis/prognostic marker of the bone metastases in patients with lung cancer especially with small-cell lung cancer.

The measurement of HE4 in the serum as a potentially useful biomarker can help in prognosis and survival of patients with lung cancer in the future. We suppose that the precise research of serum HE4 in cancer patients predominantly with lung carcinoma can help to better understand important role of this tumor marker in human body. More frequent measurements of HE4 serum concentrations in lung cancer patients in Slovakia or in Caucasian population can be helpful in management of patients with lung cancer in clinical practice.

Acknowledgment: The authors would like to thank for measurement of HE4 serum concentration levels to our colleagues from the Department of Clinical Biochemistry in the University Hospital in Martin, Comenius University in Bratislava, Slovak Republic.

\section{References}

[1] VANSTEENKISTE J, DE RUYSSCHER D, EBERHARDT WE, LIM E, SENAN S et al. Early and locally advanced nonsmall-cell lung cancer (NSCLC): ESMO Clinical Practice Guidelines for diagnosis, treatment and follow-up. Ann Oncol 2013; 24: 89-98. https://doi.org/10.1093/annonc/mdt241

[2] ETTINGER DS, WOOD DE, AKERLEY W, BAZHENOVA LA, BORGHAEI H et al. Non-Small Cell Lung Cancer, Version 6.2015. J Natl Compr Canc Netw 2015; 13: 515-524.

[3] TORRE LA, SIEGEL RL, WARD EM, JEMAL A. Global Cancer Incidence and Mortality Rates and Trends-An Update. Cancer Epidemiol Biomarkers Prev 2016; 25: 16-27. https://doi.org/10.1158/1055-9965.EPI-15-0578 
[4] BIALOUS SA, SARNA L. Lung Cancer and Tobacco: What is New? Nurs Clin North Am 2017; 52: 53-63. https://doi. org/10.1016/j.cnur.2016.10.003

[5] SHUKLA S, KHAN S, SINHA S, MEERAN SM. Lung cancer stem cells: An epigenetic perspective. Curr Cancer Drug Targets 2018 ; 18: 16-31. https://doi.org/10.2174/156800961766 6170206104623

[6] GARCIA-CAMPELO R, BERNABÉ R, COBO M, CORRAL J, COVES J et al. SEOM clinical guidelines for the treatment of non-small cell lung cancer (NSCLC) 2015. Clin Transl Oncol 2015; 17: 1020-1029. https://doi.org/10.1007/s12094015-1455-Z

[7] BRÜSKE-HOHLFELD I. Environmental and occupational risk factors for lung cancer. Methods Mol Biol 2009; 472: 3-23. https://doi.org/10.1007/978-1-60327-492-0_1

[8] PETERS S, ADJEI AA, GRIDELLI C, RECK M, KERR K et al. Metastatic non-small-cell lung cancer (NSCLC): ESMO Clinical Practice Guidelines for diagnosis, treatment and follow-up. Ann Oncol 2012; 23: 56-64. https://doi.org/10.1093/ annonc/mds226

[9] BORTOT CD, AMORIM BJ, OKI GC, GAPSKI SB, SANTOS AO et al. ${ }^{18} \mathrm{~F}-$ Fluoride PET/CT is highly effective for excluding bone metastases even in patients with equivocal bone scintigraphy. Eur J Nucl Med Mol Imaging 2012; 39: 1730-1736. https://doi.org/10.1007/s00259-012-2195-8

[10] KANE T, KULSHRESTHA R, NOTGHI A, ELIAS M. Clinical Utility(Applications) ofSPECT/CT,pp 165-222.In:DW.Jones, P. Hogg, E. Seeram (Eds.). Practical SPECT/CT in Nuclear Medicine. Springer-Verlag London, 2013, p. 354. ISBN 978-14471-4703-9. https://doi.org/10.1007/978-1-4471-4703-9_8

[11] CLAUSS A, LILJA H, LUNDWALL A. A locus on human chromosome 20 contains several genes expressing protease inhibitor domains with homology to whey acidic protein. Biochem J 2002; 368: 233-242. https://doi.org/10.1042/ BJ20020869

[12] KIRCHHOFF C. Molecular characterization of epididymal proteins. Rev Reprod 1998; 3: 86-95.

[13] KIRCHHOFF C, HABBEN I, IVELL R, KRULL N. A major human epididymis-specific cDNA encodes a protein with sequence homology to extracellular proteinase inhibitors. Biol Reprod 1991; 45: 350-357. https://doi.org/10.1095/biolreprod45.2.350

[14] CLAUSS A, LILJA H, LUNDWALL A. The evolution of a genetic locus enconding small serine proteinase inhibitors. Biochem Biophys Res Commun 2005; 333: 383-389. https:// doi.org/10.1016/j.bbrc.2005.05.125

[15] BINGLE L, CROSS SS, HIGH AS, WALLACE WA, RASSL D et al. WFDC2 (HE4): a potential role in the innate immunity of the oral cavity and respiratory tract and the development of adenocarcinomas of the lung. Respir Res 2006; 7: 61. https://doi.org/10.1186/1465-9921-7-61

[16] NOZAKI K, OGAWA M, WILLIAMS JA, LAFLEUR BJ, NG $\mathrm{V}$ et al. A molecular signature of gastric metaplasia arising in response to acute parietal cell loss. Gastroenterology 2008; 134: 511-522. https://doi.org/10.1053/j.gastro.2007.11.058

[17] KAMEI M, YAMASHITA S, TOUISHI K, HASHIOTO T, MOROGA T et al. HE4 expression can be associated with lymph node metastases and disease-free survival in breast cancer. Anticancer Res 2010; 30: 4779-4783.
[18] BIGNOTTI E, RAGNOLI M, ZANOTTI L, CALZA S, FALCHETTI $M$ et al. Diagnostic and prognostic impact of serum HE4 detection in endometrial carcinoma patients. Br J Cancer 2011; 104: 1418-1425. https://doi.org/10.1038/bjc.2011.109

[19] YAMASHITA S, TOKUISHI K, HASHIMOTO T, MOROGA T, KAMEI M et al. Prognostic significance of HE4 expression in pulmonary adenocarcinoma. Tumour Biol 2011; 32: 265-271. https://doi.org/10.1007/s13277-010-0118-5

[20] IWAHORI K, SUZUKI H, KISHI Y, FUJII Y, UEHARA R et al. Serum HE4 as a diagnostic and prognostic marker for lung cancer. Tumour Biol 2012; 33: 1141-1149. https://doi. org/10.1007/s13277-012-0356-9

[21] LI J, CHEN H, MARIANI A, CHEN D, KLATT E et al. HE4 (WFDC2) Promotes Tumor Growth in Endometrial Cancer Cell Lines. Int J Mol Sci 2013; 14: 6026-6043. https://doi. org/10.3390/ijms14036026

[22] NAGYB Jr, BHATTOA HP, STEIBERZ, CSOBAN M, SZILASI $\mathrm{M}$ et al. Serum human epididymis protein 4 (HE4) as a tumor marker in men with lung cancer. Clin Chem Lab Med 2014; 52: 1639-1648. https://doi.org/10.1515/cclm-2014-0041

[23] HELLSTRÖM I, RAYCRAFT J, HAYDEN-LEDBETTER M, LEDBETTER JA, SCHUMMER M et al. The HE4 (WFDC2) protein is a biomarker for ovarian carcinoma. Cancer Res 2003; 63: 3695-3700.

[24] MOORE RG, HILL EK, HORAN T, YANO N, KIM K et al. HE4 (WFDC2) gene overexpression promotes ovarian tumor growth. Sci Rep 2014; 4: 3574. https://doi.org/10.1038/ srep03574

[25] COLEMAN RE. Skeletal complications of malignancy. Cancer 1997; 80: 1588-1594. https://doi.org/10.1002/(sici)10970142(19971015)80:8+<1588::aid-cncr9>3.3.co;2-z

[26] COLEMAN RE. Metastatic bone disease: clinical features, pathophysiology and treatment strategies. Cancer Treat Rev 2001; 27: 165-176. https://doi.org/10.1053/ctrv.2000.0210

[27] ROSS DT, SCHERF U, EISEN MB, PEROU CM, REES C et al. Systematic variation in gene expression patterns in human cancer cell lines. Nat Genet 2000; 24: 227-235. https:// doi.org/10.1038/73432

[28] BOUCHARD D, MORISSET D, BOURBONNAIS Y, TREMBLAY GM. Proteins with whey-acidic-protein motifs and cancer. Lancet Oncol 2006; 7: 167-174. https:/doi. org/10.1016/S1470-2045(06)70579-4

[29] HUHTINEN K, SUVITIE P, HIISSA J, JUNNILA J, HUVILA J et al. Serum HE4 concentration differentiates malignant ovarian tumours from ovarian endometriotic cysts. Br J Cancer 2009; 100: 1315-1319. https://doi.org/10.1038/sj.bjc.6605011

[30] ESCUDERO JM, AUGE JM, FILELLA X, TORNE A, PAHISA J et al. Comparison of serum human epididymis protein 4 with cancer antigen 125 as a tumor marker in patients with malignant and nonmalignant diseases. Clin Chem 2011; 57: 1534-1544. https://doi.org/10.1373/clinchem.2010.157073

[31] KARLSEN MA, SANDHU N, HOGDALL C, CHRISTENSEN IJ, NEDERGAARD L et al. Evaluation of HE4, CA125, risk of ovarian malignancy algorithm (ROMA) and risk of malignancy index (RMI) as diagnostic tools of epithelial ovarian cancer in patients with a pelvic mass. Gynecol Oncol 2012; 127: 379-383. https://doi.org/10.1016/j.ygyno.2012.07.106 
[32] GARBER ME, TROYANSKAYA OG, SCHLUENS K, PETERSEN S, THAESLER Z et al. Diversity of gene expression in adenocarcinoma of the lung. Proc Natl Acad Sci U S A 2001; 98: 13784-13789. https://doi.org/10.1073/ pnas. 241500798

[33] GALGANO MT, HAMPTON GM, FRIERSON HF Jr. Comprehensive analysis of HE4 expression in normal and malignant human tissues. Mod Pathol 2006; 19: 847-853. https:// doi.org/10.1038/modpathol.3800612

[34] HERTLEIN L, STIEBER P, KIRSCHENHOFER A, KROCKER K, NAGEL D et al. Human epididymis protein 4 (HE4) in benign and malignant diseases. Clin Chem Lab Med 2012; 50: 2181-2188. https://doi.org/10.1515/cclm-2012-0097

[35] CHENG D, SUN Y, HE H. The diagnostic accuracy of HE4 in lung cancer: a meta-analysis. Dis Markers 2015: 352670. https://doi.org/10.1155/2015/352670

[36] TANG QF, ZHOU ZW, JI HB, PAN WH, SUN MZ. Value of serum marker HE4 in pulmonary carcinoma diagnosis. Int J Clin Exp Med 2015; 8: 19014-19021.

[37] DRAPKIN R, VON HORSTEN HH, LIN Y, MOK SC, CRUM $\mathrm{CP}$ et al. Human epididymis protein 4 (HE4) is a secreted glycoprotein that is overexpressed by serous and endometrioid ovarian carcinomas. Cancer Res 2005; 65: 2162-2169. https://doi.org/10.1158/0008-5472.CAN-04-3924

[38] WEISSENSTEINER J, BABUŠÍKOVÁ E. Bone metabolism of the Patient with a Malignant Melanoma during the Entry Examination and the Check-up of Whole-body Bone Scintigraphy. Prague Med Rep 2016; 117: 129-134. https://doi. org/10.14712/23362936.2016.14

[39] ZENG Q, LIU M, ZHOU N, LIU L, SONG X. Serum human epididymis protein 4 (HE4) may be a better tumor marker in early lung cancer. Clin Chim Acta 2016; 455: 102-106. https://doi.org/10.1016/j.cca.2016.02.002

[40] YAMASHITA S, TOKUISHI K, MOROGA T, YAMAMOTO $\mathrm{S}, \mathrm{OHBO} \mathrm{K}$ et al. Serum level of HE4 is closely associated with pulmonary adenocarcinoma progression. Tumour Biol 2012; 33: 2365-2370. https://doi.org/10.1007/s13277-012-0499-8

[41] LIU W, YANG J, CHI PD, ZHENG X, DAI SQ et al. Evaluating the clinical significance of serum HE4 levels in lung cancer and pulmonary tuberculosis. Int J Tuberc Lung Dis 2013; 17: 1346-1353. https://doi.org/10.5588/ijtld.13.0058
[42] WANG X, FAN Y, WANG J, WANG H, LIU W. Evaluating the expression and diagnostic value of human epididymis protein 4 (HE4) in small cell lung cancer. Tumour Biol 2014; 35: 6847-6853. https://doi.org/10.1007/s13277-014-1943-8

[43] HUANG W, WU S, LIN Z, CHEN P, WU G. Evaluation of HE4 in the Diagnosis and Follow Up of Non-Small Cell Lung Cancers. Clin Lab 2017; 63: 461-467. https://doi. org/10.7754/Clin.Lab.2016.160818

[44] WOJCIK E, TARAPACZ J, RYCHLIK U, STASIK Z, SASKORCZYNSKA B et al. Human epididymis protein 4 (HE4) in patients with small-cell lung cancer. Clin Lab 2016; 62: 1625-1632. https://doi.org/10.7754/Clin.Lab.2016.151212

[45] CELIK B, BULUT T. Human epididymis protein 4 may not be a reliable screening biomarker for detecting lung carcinoma patients. Biomedical Reports 2017; 7: 297-300. https:// doi.org/10.3892/br.2017.971

[46] LAN WG, HAO YZ, XU DH, WANG P, ZHOU YL et al. Serum human epididymis protein 4 is associated with the treatment response of concurrent chemoradiotherapy and prognosis in patients with locally advanced non-small cell lung cancer. Clin Transl Oncol 2016; 18: 375-380. https:// doi.org/10.1007/s12094-015-1375-y

[47] DAI C, ZHENG Y, LI Y, TIAN T, WANG M et al. Prognostic values of HE4 expression in patients with cancer: a metaanalysis. Cancer Manag Res 2018; 10: 4491-4500. https://doi. org/10.2147/CMAR.S178345

[48] LEE S, CHOI S, LEE Y, CHUNG D, HONG S et al. Role of human epididymis protein 4 in chemoresistance and prognosis of epithelial ovarian cancer. J Obstet Gynaecol Res 2017; 43: 220-227. https://doi.org/10.1111/jog.13181

[49] JIANG Y, WANG C, LV B, MA G, WANG L. Expression level of serum human epididymis 4 and its prognostic significance in human non-small cell lung cancer. Int J Clin Exp Med 2014; 7: 5568-5572.

[50] LAMY PJ, PLASSOT C, PUJOL JL. Serum HE4: An Independent Prognostic Factor in Non-Small Cell Lung Cancer. PLoS One 2015; 10: e0128836. https://doi.org/10.1371/journal.pone. 0128836 